\title{
Hubungan Pengetahuan dengan Praktik Perawatan Diri pada Pasien Diabetes Mellitus Tipe 2 di Surakarta
}

\section{Relationship between Knowledge and Self Care Practice among Patient with Type 2 Diabetes Mellitus in Surakarta}

\author{
Akhmad Azmiardi ${ }^{1}$ \\ Program Studi Kesehatan Masyarakat,Universitas Veteran Bangun Nusantara ${ }^{I}$ \\ Email :aazmiardi@gmail.com.
}

\begin{abstract}
This study aimed to examine the relationship between knowledge and self care practice among patient with type 2 diabetes mellitus in Surakarta.This was an observational analytic study with cross sectional approach. This study was conducted at Surakarta on June to July 2019. A total of 200 patiens with type 2 diabetes mellitus was selected for this study by simple random sampling. Variable dependent in this study was self care practice. Variable independent in this study was knowledge. The data of self care practice and knowledge were collected by questionnaire. The data were analyzed by a chisquare. The result showed that there was relationship between knowledge and self care practice among patient with type 2 diabetes mellitus and statistically significant $(\mathrm{OR}=$ $5.58 ; 95 \% \mathrm{CI}=3.03$ to $10.28 ; \mathrm{p}<0.001)$. Patients with better knowledge has chance to practice better self care behavior 5.58 times than patient with poor knowledge.
\end{abstract}

Keywords: knowledge, self care practice, type 2 diabetes mellitus

\begin{abstract}
ABSTRAK
Penelitian ini bertujuan untuk mengetahui hubungan pengetahuan dengan praktik perawatan diri pada pasien diabetes mellitus tipe 2 di Surakarta. Penelitian ini merupakan observational analitik dengan desain penelitian cross sectional. Penelitian ini di lakukan di Kota Surakarta dari bulan Juni hingga Juli 2019. Sebanyak 200 pasien diabetes mellitus tipe 2 di pilih dengan menggunakan teknik simple random sampling. Variabel dependen dalam penelitian ini adalah praktik perawatan diri. Variabel independen dalam penelitian ini adalah pengetahuan. Data praktik perawatan diri pengetahuan diperoleh dengan menggunakan kuisioner. Data yang diperoleh dianalisis menggunakan chi square. Hasil analisis menunjukkan terdapat hubungan antara pengetahuan dengan praktik perawatan diri pada pasien DM tipe 2 dan ada hubungan secara statistik signifikan (OR=5.58; CI 95\%= 3.03 hingga 10.28; $\mathrm{p}<0.001$ ). Pasien DM tipe 2 dengan pengetahuan tinggi mempunyai peluang untuk melakukan praktik perawatan diri yang lebih baik 5.58 kali daripada pasien DM tipe 2 dengan pengetahuan rendah.
\end{abstract}

Kata kunci: pengetahuan, praktik perawatan diri, diabetes mellitus tipe 2

\section{PENDAHULUAN}

Diabetes mellitus tipe 2 adalah penyakit kronis dengan prevalensi yang meningkat dengan cepat di seluruh dunia. Angka prevalensi diabetes mellitus tipe 2 lebih tinggi pada negara-negara berpenghasilan rendah dan menengah seperti Indonesia. Dengan tingkat prevalensi keseluruhan $8.5 \%$, Indonesia memiliki populasi penderita diabetes terbesar ke-6 di dunia (International Diabetes Federation (IDF), 2017). 
Sedangkan di Indonesia berdasarkan riskesdas dari 2013 hingga 2018 prevalensi Diabetes Melitus (DM) meningkat dari 6,9 persen menjadi 8,5 persen, yang artinya ada kurang 22,9 juta penduduk prevalensi DM. Ada beragam kendala mengapa angka terjadi salah satunya kondisi demografi Indonesia. Peningkatan prevalensi DM disebabkan antara lain karena Indonesia saat ini berada dalam masa transisi, demografi, teknologi, epidemiologi, budaya, ekonomi, tingkat pengetahuan dan lain-lain (Kementerian Kesehatan Republik Indonesia, 2018).

Pengetahuan pasien tentang penyakit dan praktik perawatan diri ditemukan penting bagi pasien untuk mencapai target pengobatan yang diinginkan dan berkontribusi secara bermakna dalam pengelolaan penyakit. Pengetahuan diabetes dianggap sebagai hal yang penting untuk melaksanakan kegiatan perawatan diri yang efektif demi hasil kesehatan yang baik seperti mencegah komplikasi dan kematian (Hailu, Moen and Hjortdahl, 2019).

Pengetahuan diabetes telah diidentifikasi sebagai salah satu hal yang sangat penting untuk intervensi diabetes karena pengetahuan diabetes dan praktik perawatan diri secara signifikan terkait dengan kontrol glikemik. Pengetahuan tentang penyakit ini cenderung untuk menginformasikan pasien tentang tindakan spesifik dalam proses manajemen diabetes. Dengan demikian, semakin banyak pengetahuan pasien tentang penyakit mereka, semakin besar kemungkinan mereka untuk memahami penyakit mereka dan melakukan praktik perawatan diri seperti diet, olahraga dan monitoring gula darah (Kugbey, Oppong Asante and Adulai, 2017).

Kepatuhan dalam manajemen praktik perawatan diri seperti olahraga, makan makanan sehat dan rendah gula, minum obat secara benar dan teratur menjadi strategi dan kunci utama dalam mencegah perkembangan penyakit ke arah berat hingga menimbulkan komplikasi yang dapat mencegah kematian dan meningkatkan kualitas hidup pasien diabetes mellitus tipe 2 (Shrivastava, Shrivastava and Ramasamy, 2013). Penelitian ini bertujuan untuk mengetahui hubungan pengetahuan dengan praktik perawatan diri pada pasien diabetes mellitus tipe 2 di Surakarta.

\section{METODE}

Penelitian ini merupakan observational analitik dengan desain penelitian cross sectional. Penelitian ini di lakukan di RSUD Kota Surakarta dari bulan Juni hingga Juli 2019. Subjek penelitian dalam penelitian ini adalah pasien dengan diagnosa diabetes mellitus tipe 2. Besar sampel dalam penelitian ini adalah 200 orang pasien diabetes mellitus tipe 2. Subjek penelitian di pilih dengan menggunakan teknik simple random sampling. Variabel dependen dalam penelitian ini adalah praktik perawatan diri. Variabel independen dalam penelitian ini adalah pengetahuan. Data praktik perawatan diri pengetahuan diperoleh dengan menggunakan kuisioner. Data yang diperoleh dianalisis menggunakan chi square.

\section{HASIL DAN PEMBAHASAN}

\section{Karakteristik Subjek Penelitian}

Berdasarkan tabel 1 pada karakteristik subjek penelitian menunjukkan bahwa jenis kelamin subjek penelitian penelitian pasien DM tipe 2 terbanyak yaitu jenis kelamin perempuan, dengan jumlah yaitu sebanyak 132 orang (66\%). Umur subjek penelitian yang paling banyak yaitu berusia 46 hingga 55 tahun yaitu sebanyak 79 orang (39.5\%) sedangkan yang paling sedikit berusia 34 hingga 45 tahun yaitu sebanyak 27 orang $(13.5 \%)$.

Pendidikan terakhir subjek penelitian pada pasien DM tipe 2 dibagi menjadi 5 katergori yang terdiri dari tidak sekolah, SD, SMP, SMA, dan perguruan tinggi sebagian 
besar memiliki tingkat pendidikan SMP yaitu sebanyak 69 orang (34.5\%). Jenis pekerjaan subjek penelitian pada kelompok kasus terbanyak adalah swasta yaitu 97 orang (48.5\%).

Tabel 1. Karakteristik Subjek Penelitian

\begin{tabular}{llcc}
\hline Karateristik & Kriteria & Frekuensi (n) & Persentase (\%) \\
\hline Usia & 36-45 Tahun & 27 & 13.5 \\
& 46-55 Tahun & 79 & 39.5 \\
& 56-65 Tahun & 53 & 26.5 \\
\multirow{3}{*}{ Jenis Kelamin } & 266 Tahun & 41 & 20.5 \\
Tingkat Pendidikan & Laki-laki & 68 & 34.0 \\
& Perempuan & 132 & 66.0 \\
& Tidak Sekolah & 20 & 10.0 \\
& SD & 42 & 21.0 \\
& SMP & 69 & 34.5 \\
Pekerjaan & SMA & 62 & 31.0 \\
& PT & 7 & 3.5 \\
& Tidak Berkerja & 35 & 17.5 \\
& IRT & 33 & 16.5 \\
& Petani & 15 & 7.5 \\
& Swasta & 97 & 48.5 \\
& PNS & 8 & 4.0 \\
& Pensiunan & 12 & 6.0 \\
\hline
\end{tabular}

\section{Analisis Bivariat}

Berdasarkan tabel 2. menunjukkan hubungan pengetahuan dengan praktik perawatan diri pada pasien DM tipe 2 . Sebesar $66.7 \%$ atau sebanyak 60 orang pasien DM tipe 2 dengan praktik perawatan diri tinggi juga mempunyai pengetahuan tinggi. Sebaliknya sebesar $73.6 \%$ atau sebanyak 81 pasien DM tipe 2 dengan praktik perawatan diri yang rendah juga memiliki pengetahuan yang rendah. Hasil analisis dengan uji Chi Square menunjukkan bahwa pasien DM tipe 2 dengan pengetahuan tinggi mempunyai peluang untuk melakukan praktik perawatan diri yang lebih baik 5.58 kali daripada pasien DM tipe 2 dengan pengetahuan rendah dan ada hubungan secara statistik signifikan antara pengetahuan dengan praktik perawatan diri pada pasien DM tipe $2(\mathrm{OR}=5.58$; CI 95\%= 3.03 hingga $10.28 ; \mathrm{p}=<0.001)$.

Tabel 2. Analisis Bivariat

\begin{tabular}{|c|c|c|c|c|c|c|c|c|c|c|}
\hline \multirow{3}{*}{ Variabel } & \multicolumn{4}{|c|}{ Praktik perawatan diri } & \multirow{2}{*}{\multicolumn{2}{|c|}{ Total }} & \multirow{3}{*}{ OR } & \multicolumn{2}{|c|}{ CI 95\% } & \multirow{3}{*}{$\mathbf{p}$} \\
\hline & \multicolumn{2}{|c|}{ Rendah } & \multicolumn{2}{|c|}{ Tinggi } & & & & \multirow{2}{*}{$\begin{array}{l}\text { Batas } \\
\text { atas }\end{array}$} & \multirow{2}{*}{$\begin{array}{l}\text { Batas } \\
\text { bawah }\end{array}$} & \\
\hline & $\mathbf{N}$ & $\%$ & $\mathbf{N}$ & $\%$ & $\mathbf{N}$ & $\%$ & & & & \\
\hline \multicolumn{11}{|c|}{ Pengetahuan } \\
\hline Rendah & 81 & 73.6 & 29 & 26.4 & 110 & 100 & 5.58 & 3.03 & 10.28 & $<0.001$ \\
\hline Tinggi & 30 & 33.3 & 60 & 66.7 & 90 & 100 & & & & \\
\hline
\end{tabular}

Penelitian ini menunjukkan bahwa terdapat hubungan antara pengetahuan terhadap praktik perawatan diri. Hasil analisis diketahui bahwa pengaruh positif pada pasien dengan pengetahuan tentang diabetes melitus tipe 2 yang tinggi akan meningkatkan praktik perawatan diri terhadap diabetes melitus tipe 2 .

\section{KESIMPULAN}

Terdapat hubungan antara pengetahuan dengan praktik perawatan diri pada pasien DM tipe 2. Hasil analisis menunjukkan bahwa pasien DM tipe 2 dengan pengetahuan 
tinggi mempunyai peluang untuk melakukan praktik perawatan diri yang lebih baik 5.58 kali daripada pasien DM tipe 2 dengan pengetahuan rendah dan secara statistik signifikan.

Hasil penelitian ini sejalan dengan hasil penelitian di India yang menyebutkan bahwa pengetahuan pasien tentang diabetes melitus tipe 2 berhubungan dengan praktik perawatan diri, seperti, aktifitas fisik, diet sehat dan kepatuhan pengobatan. Semakin baik pengetahuan pasien maka semakin rutin pula perawatan diri diabetes yang dilakukan oleh pasien (Dinesh, Kulkarni and Gangadhar, 2016).

Temuan penelitian saat ini sesuai dengan hasil dari studi Kassahun et al yang mengungkapkan tingkat pengetahuan diabetes yang rendah di antara responden penelitian yang juga menunjukkan memiliki praktik perawatan diri yang buruk dan kepatuhan yang rendah terhadap pengobatan (Kassahun, Eshetie and Gesesew, 2016).

Temuan ini konsisten dengan hasil sebelumnya yang menemukan pengetahuan diabetes sebagai prediktif praktik perawatan mandiri diabetes dan manajemen diabetes. Pengetahuan tentang diabetes berpengaruh pada praktik perawatan diri secara keseluruhan hasil analisis menunjukkan bahwa pengetahuan diabetes secara signifikan dan positif memprediksi praktik perawatan mandiri diabetes secara keseluruhan yaitu Praktik perawatan-diri terkait-diabetes, seperti, praktik makan sehat, aktivitas fisik, pemantauan glukosa darah, dan mengikuti terapi glikemik yang direkomendasikan. Ini menunjukkan bahwa semakin banyak pengetahuan pasien diabetes tentang penyakit mereka, semakin besar kemungkinan mereka terlibat dalam praktik perawatan diri diabetes (Kugbey, Oppong Asante and Adulai, 2017).

Temuan ini juga konsisten dengan penelitian lain yang dilakukan di Ethiopia yang menyatakan bahwa pengetahuan yang buruk tentang diabetes berkaitan secara signifikan dengan praktik perawatan diri yang buruk. Hal ini dapat dijelaskan karena pasien dengan pengetahuan yang buruk tentang diabetes kurang patuh terhadap pengobatan dan praktik perawatan diri mereka dan ini akan mengakibatkan kontrol glikemik yang buruk (Dedefo et al., 2019).

Dengan demikian, temuan ini menginformasikan perlunya memiliki pendidikan diabetes untuk mengatasi masalah yang berkaitan dengan praktik perawatan diri. Strategi yang komprehensif dan efektif terdiri dari tindakan untuk menerapkan praktik perawatan diri yang konsisten seperti pola diet yang baik, aktivitas fisik yang teratur, kontrol glikemik mandiri dan perawatan kaki harus di terapkan. Sekali lagi bahwa pendidikan kesehatan untuk pasien yang menderita penyakit kronis merupakan hal yang penting untuk meningkatkan praktik perawatan diri diabetes agar dapat bermanfaat bagi pasien dalam mencapai kontrol glikemik yang diinginkan.

\section{SARAN}

Hasil studi pada penelitian ini diharapkan dapat dijadikan acuan untuk peneliti selanjutnya dengan menambahkan variabel lain seperti efikasi diri dan dukungan keluarga serta metode penelitian yang lain yaitu dengan wawancara mendalam pada pasien dan keluarganya, sehingga dapat menggali informasi lebih dalam terhadap upaya meningkatkan praktik perawatan diri yang baik pada pasien DM tipe 2 . 


\section{DAFTAR PUSTAKA}

Dedefo, M. G. et al. (2019) 'Self-care practices regarding diabetes among diabetic patients in West Ethiopia', BMC Research Notes. BioMed Central Ltd., 12(1), p. 212. doi: 10.1186/s13104-019-4258-4.

Dinesh, P., Kulkarni, A. and Gangadhar, N. (2016) 'Knowledge and self-care practices regarding diabetes among patients with Type 2 diabetes in Rural Sullia, Karnataka: A community-based, cross-sectional study', Journal of Family Medicine and Primary Care. Medknow, 5(4), p. 847. doi: 10.4103/2249-4863.201176.

Hailu, F. B., Moen, A. and Hjortdahl, P. (2019) 'Diabetes self-management education (DSME) - Effect on knowledge, self-care behavior, and self-efficacy among type 2 diabetes patients in Ethiopia: A controlled clinical trial', Diabetes, Metabolic Syndrome and Obesity: Targets and Therapy. Dove Medical Press Ltd., 12, pp. 2489-2499. doi: 10.2147/DMSO.S223123.

International Diabetes Federation (IDF) (2017) Eighth edition 2017, IDF Diabetes Atlas, 8th edition. doi: http://dx.doi. org/10.1016/S0140-6736(16)31679-8.

Kassahun, T., Eshetie, T. and Gesesew, H. (2016) 'Factors associated with glycemic control among adult patients with type 2 diabetes mellitus: a cross-sectional survey in Ethiopia', BMC Research Notes, 9(1), p. 78. doi: 10.1186/s13104-016-1896-7.

Kementerian Kesehatan Republik Indonesia (2018) 'Tahun 2030 Prevalensi Diabetes Melitus Di Indonesia Mencapai 21,3 Juta Orang', www.depkes.go.id. doi: $10.1145 / 2818346.2820736$.

Kugbey, N., Oppong Asante, K. and Adulai, K. (2017) 'Illness perception, diabetes knowledge and self-care practices among type-2 diabetes patients: A cross-sectional study', BMC Research Notes. BioMed Central Ltd., 10(1). doi: 10.1186/s13104-0172707-5.

Shrivastava, S. R. B. L., Shrivastava, P. S. and Ramasamy, J. (2013) 'Role of self-care in management of diabetes mellitus', Journal of Diabetes and Metabolic Disorders. Springer, p. 14. doi: 10.1186/2251-6581-12-14. 